\title{
A Tribute to José María (“Chema”) Cantú
}

\author{
Victor B. Penchaszadeh ${ }^{1}$, Augusto Rojas-Martinez ${ }^{2}$ and Adrián Llerena ${ }^{3}$ \\ ${ }^{1}$ Department of Health Sciences, National University of La Matanza, Buenos Aires, Argentina. \\ ${ }^{2}$ Department of Biochemistry and Molecular Medicine, School of Medicine and Center for Research and \\ Development in Health Sciences, Autonomous University of Nuevo León, Monterrey, México. \\ ${ }^{3}$ Clinical Research Center, Extremadura University Hospital and Medical School, Badajoz, Spain.
}

\begin{abstract}
José María ("Chema") Cantú (1938-2007), born in Mexico, was a pioneering, loved and respected leader in medical and human genetics and bioethics in Latin America. He graduated as a physician in Mexico and then trained in medical and human genetics in France and the United States. He was instrumental in developing a first-rate research, training and genetic services program in medical and human genetics in Guadalajara, in northwestern Mexico. He acted forcefully at national, regional and international levels to promote scientific development through collaboration and education in science and humanities, while he simultaneously strived for justice, peace, love and human rights. He attained some of the highest honors a scientist and humanist could aspire to as well as the recognition of the communities he served. Hundreds of disciples throughout Latin America and the world have been inspired by his vision of a better world through the conjunction of science, respect for humankind, ethics and love.
\end{abstract}

Keywords: Cantú José María, medical genetics, human genetics, bioethics, Latin America.

José María ("Chema") Cantú (1938-2007), born in Monterrey, Mexico (Figure 1), was an exceptional human being and human geneticist concerned as much with his science as with the ethical imperative that scientific knowledge should be used only for the good of humankind. This deeply rooted conviction has been Chema Cantú's guiding principle in life, which earned him admiration and respect from colleagues and friends throughout the world during his long career.

One of us (VBP) met Chema for the first time in 1972 at the International Congress of Human Genetics in Paris, after which a very close friendship developed and was nurtured by a common, progressive vision of the social and scientific challenges faced by developing countries, specifically in the nascent field of human genetics. From then on, and until his premature death in Buenos Aires on November 12, 2007, we collaborated on many projects to develop the field of human genetics in Latin America, both at the level of basic research as well as in its applications for human health and wellbeing, respecting ethical principles and human dignity.

Chema Cantú graduated as a physician in 1965 from the National University of Mexico, and he pursued postgraduate training in human genetics under J. De Grouchy at

Send correspondence to Victor B. Penchaszadeh. Department of Health Sciences, National University of La Matanza, República de la India 2873, 1425 Buenos Aires, Argentina. E-mail: victorpenchas@gmail.com. the Hôpital des Enfants Malades in Paris (1965-1967), followed by a research fellowship in reproductive genetics at George Washington University. Upon his return to Mexico in 1968, he became a medical geneticist at the Instituto Mexicano del Seguro Social (IMSS), the powerful social security institution that provides medical and social services to more than half the Mexican population. However, at that time, the field of medical and human genetics in Mexico was centered almost exclusively in Mexico City, and soon, Chema realized that there was a need to decentralize and expand the field in other areas of the country. He therefore proposed a new genetics center at the IMSS in Guadalajara, Jalisco, which was eventually approved, and in 1976, this was where he was appointed Chief of the Division of Genetics of the Centro de Investigación Biomédica de Occidente, a position he retained until his retirement in 2001. The challenge of developing the field of human genetics in Guadalajara, far from the center of Mexican political, economic and scientific power, was met by Chema with outstanding skill and leadership. His incredible charisma and humanity commanded an enthusiastic cadre of junior physician-scientists and young students who soon began to provide genetic services in what were until then completely underserved areas. Soon, Chema Cantú's Guadalajara genetics group transformed the Mexican human genetics landscape, developing comprehensive clinical genetics services in the state of Jalisco and acquiring recogni- 


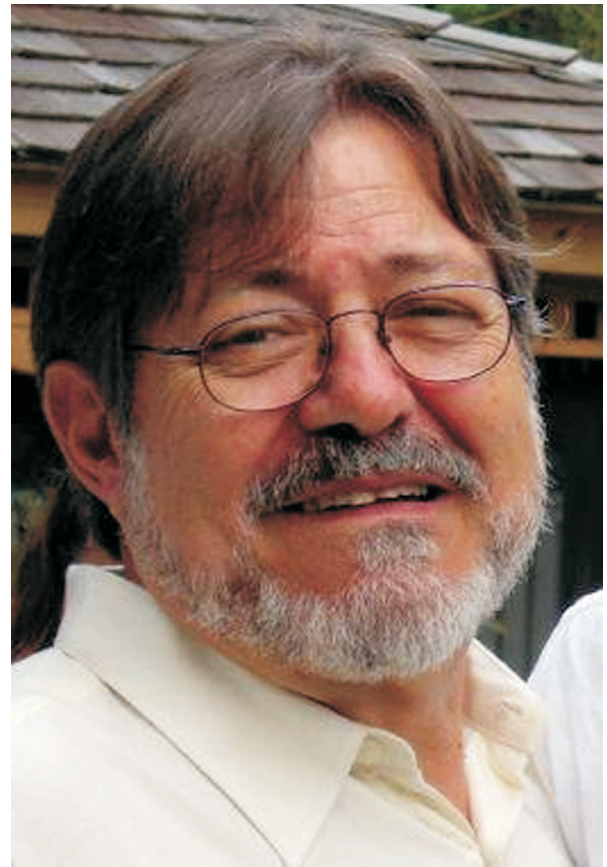

Figure 1 - José María Cantú.

tion in the international literature with descriptions of more than 20 previously unknown hereditary conditions.

Being a champion of academic pursuits, he created several postgraduate training programs in medical and human genetics: initially, a certificate specialist-training program (1977-1985) and, later, a Master (1985-present) and a Doctorate program (1996-present), which are still being offered by an agreement between the Centro de Investigación Biomédica de Occidente of the IMSS and the Graduate School of the University of Guadalajara. According to his personal conviction that education is a human right that should be honored by the government, the training programs included many foreign students who arrived in Guadalajara to pursue their graduate studies in what was, at the time, one of the most attractive centers for human genetic studies in Latin America. According to Chema's vision and philosophy, these training programs were open to all professionals interested in human and medical genetics and not only to physicians. Training included physical examination, dysmorphology, the design and execution of family studies, cytogenetics, molecular genetics, genetic counseling and the writing of scientific articles. Further multidisciplinary developments of genetics and genomics at the beginning of the 21 st century validated Chema's educational vision. Courses were complemented by the provision of comprehensive genetic services to patients with conditions involving multiple specialties. As a student, one of us (ARM) had the personal honor of being mentored by one of the first and closest disciples of Chema, Dr. Diana GarcíaCruz, and later, by Chema himself. These two mentors excelled in the physical examination and definition of patient phenotypes, including minor morphological and behavioral variations that usually would be unnoticed by most physicians, such as oral-facial and body proportions, peculiarities of the skin and its annexes, the configuration and dimensions of the external genitalia, hands and feet and many other physical features. Chema and Diana had an extraordinary capacity to recall phenotypic variants, which was particularly useful at a time when there were no electronic resources, and medical geneticists only had pictures published in medical journals and the first published dysmorphology atlases. Thus, it is not surprising that the Guadalajara group led by Chema came to be one of the most prestigious groups of "genetic syndrome hunters" in Latin America and the Caribbean, with approximately 70 entries in Mendelian Inheritance in Man. Furthermore, the training programs Chema led were a magnet for many young physicians and biomedical scientists from all over Latin America for many years. Many of his former trainees are now in key genetics faculty positions in a number of academic institutions in Mexico, Latin America and the United States.

Chema's group contributed to the molecular and phenotypic delineation of various syndromes, such as some camptodactyly-associated syndromes, X-linked mental retardation and a monogenic form of early-onset Alzheimer's disease. He paid particular attention to syndromes associated with hypertrichosis, an example of which is the condition that is named after him (Cantú et al., 1982; GarcíaCruz et al., 1997), "hypertrichotic osteochondrodysplasia" (OMIM \#239850). The ABCC9 gene, responsible for this autosomal dominant syndrome, was discovered recently and simultaneously by two Dutch groups by exome sequencing, and it encodes a potassium ATP-dependent channel protein $\left(\mathrm{K}_{\mathrm{ATP}}\right)$ (Harakalova et al., 2012; van Bon et al., 2012). Mutations associated with the phenotype resemble the effect of minoxidil, an antihypertensive drug that induces hypertrichosis, suggesting that a pharmacologic protein antagonist could serve as a possible drug for the treatment of hypertrophic cardiomyopathy and the pericardial effusion associated with Cantú syndrome (van Bon, 2012). Unfortunately, Chema did not witness these discoveries and the possibility of a therapy for the syndrome he described.

Another syndrome with hypertrichosis identified by the group in Guadalajara is congenital generalized hypertrichosis (OMIM \#307150) (Macias-Flores et al., 1984), an $\mathrm{X}$-linked trait. This disorder is caused by a palindromemediated interchromosomal insertion at chromosome Xq27.1, identified via copy number variation (CNV) microarray analysis and next generation sequencing (Zhu et $a l ., 2011)$. The inserted segment introduces regulatory elements that most likely alter the expression of the SOX3 gene, which is involved in the development of hair follicles, and thus produce widespread hypertrichosis, a trait that was presumably present in the ancestors of Homo sapiens. Chema was very intrigued with the idea that the hypertrichosis observed in Mexican patients is an example of an 
"atavistic mutation". The concept of "atavistic traits" was postulated by B.K. Hall (Hall, 1984), who defined it as "the reappearance of a lost character (morphology or behaviour) typical of remote ancestors and not observed in the parents or ancestors" and was a repeated theme of Chema's writings and academic arguments (Cantú and Ruiz, 1985). Future molecular studies of human evolution might throw light on controversial evolutionary mechanisms and on the role of atavistic traits in human and medical genetics.

Chema Cantú had a passion for scientific excellence, which was coupled with a passion for justice, equity and human rights, particularly the right to health. In the field of research, while he practiced and taught the rigor of the experimental scientific method developed by Western biomedicine, he was very much aware and respectful of the diversity of world views among different cultures. His admiration for the ways different cultures would approach life, health and death was the subject of his many lectures at countless international conferences. He particularly admired the Huichols, a Native American culture of Northwestern Mexico, on whom he performed genetic studies while simultaneously learning and respecting their worldview and customs (Rangel-Villalobos et al., 2000). He was also acutely aware of the unjust wealth distribution in the world and was convinced that, through dialogue among well-meaning people of different convictions, a more humane world could be achieved.

Chema was a man who could not go unnoticed because he was intensely charismatic and distilled a personal warmth that would open every type of barrier to communication and dialogue. In parallel to his local work in Jalisco, he took his passions and charisma throughout Latin America and the world, developing strong friendships and connections with anyone interested in science, justice and human rights. He was very much attracted by the philosophies of Hinduism and Buddhism. His lectures were a real treat because he reveled in telling marvelous stories of peoples and cultures he encountered in his many travels. The one culture he particularly liked to talk about was that of the followers of Jainism in India, whose norms he took as the maximum expression of respect for life and ecological soundness because they would go around naked and avoid any form of nutrition that required the killing of any living creature, animal or plant (Cantú, 2005).

Chema Cantú was a founding member of the Mexican Association of Human Genetics in 1968 and was its president between 1995 and 1999, and in 1976, he was a founder of the Mexican Council of Genetics, a certifying body for the practice of medical genetics in the country. Additionally, he participated in the growing movement of Latin American genetics as an active member of the Latin American Genetic Association (Asociación Latinoamericana de Genética, ALAG), founded in 1969 and of which he eventually became president. He received the National Award of the IMSS in 1992 and the Award FUNSALUD-Ciencias from the Fundación Mexicana de la Salud, capítulo Jalisco in 1993. In 2001, he was founder and first president of the Latin American Network of Human Genetics (Red Latinoamericana de Genética Humana, RELAGH), president of the Latin American Human Genome Program (Programa Latinoamericano del Genoma Humano, PLAGH) and president of the Mexican chapter of the Latin American Network of Biological Sciences (Red Latinoamericana de Ciencias Biológicas, RELAB). In 2006, he received a doctorate honoris causa from the Universidad Ricardo Palma, Lima, Peru, and in 2007, he was appointed as a member of the Health Committee of the Iberoamerican Program of Science and Technology for Development (CYTED). One of the honors he most valued was that in 2003 the city of Reynosa, Tamaulipas, where he grew up, gave his name to the town's general hospital, which has since been the "Dr. José María Cantú Hospital" (García-Ortiz, 2008). Chema's excellence in human genetics has also been recognized internationally. In 1992, he was appointed as a member of the Panel of Experts in Human Genetics of the World Health Organization, and in 1993, he became a member of the Permanent Committee on Scientific and Ethical Responsibility (SCRES) of the International Council of Scientific Unions (ICSU), with headquarters in Oslo, Norway. In 1999, he was elected as a member of the Board of Directors of the Human Genome Organization (HUGO), a position he kept until 2004, after which he became a member of its Ethics Committee. In 2004, the International Federation of Human Genetic Societies elected him to represent Latin America in its Steering Committee, and by 2006, he became president of the Federation, a position he was still holding at the time of his premature death. Having belonged to the Mexican National System of Researchers throughout his professional life, he was awarded the highest position of National Emeritus Researcher only a few weeks before his death.

Chema Cantú was a prolific scientific writer, with more than 350 original and peer-reviewed articles and more than 50 book chapters on genetics and bioethics. He was a member of the editorial committees of Clinical Genetics, Annales de Génétique and Archives of Medical Research as well as a reviewer for many journals, including the American Journal of Medical Genetics. His recognition by international associations and organizations dealing with genetics, science and bioethics is attested by the more than 20 awards he received. As mentioned above, Chema was a firm believer in the value of education as a path to excellence. After his retirement in 2001, as head of genetics at the IMMS's Centro de Investigación Biomédica de Occidente, he remained at the University of Guadalajara as a professor of genetics, and in 2004, when the Latin American School of Medical and Human Genetics was created at the Universidade Federal de Rio Grande do Sul, in Porto Alegre, Brazil under the leadership of Roberto Giugliani, Chema was a key member of its Scientific Committee, as 
well as a faculty member at the School's one-week immersion institute, where every year for the past 10 years, over 80 gifted graduate students from Latin America have been learning about the cutting edge of medical and human genetics.

Parallel to his convictions regarding the power of education, Chema was equally convinced of the fundamental importance of international collaboration in science and technology, and particularly that of South-South collaboration, with the synergistic aims of breaking the dependence on the North and improving the situation of vulnerable and poor populations of developing countries. An example of one such collaboration initiative fostered by Chema Cantú was the Ibero-Latin-American Network of Pharmacogenetics and Pharmacogenomics, RIBEF (de Andrés et al., 2012; Llerena et al., 2013), in which one of us (ALL) collaborated closely with Chema in congregating geneticists and pharmacologists from Spain and most Latin American countries in a network with the objectives of training and technology transfer in pharmacogenomics and the creation of databases of population studies of diseases and drugs in the participating countries. The performance of the network has been extremely successful, having yielded published pharmacogenetic studies of Mexican, Cuban, Nicaraguan, Ecuadorean and Spanish populations (de Andrés et al., 2012; Llerena et al., 2013) and a number of forthcoming publications on genetic polymorphisms most relevant for drug metabolism. These studies have been the basis for a number of doctoral and master theses of trainees in many countries in Latin America. Furthermore, a number of training workshops and seminars directed by one of us (ALL) have taken place in the host countries, in keeping with Chema's values and vision that biotechnological development should contribute to the reduction of the disease burden in poor countries instead of increasing the gap between rich and poor countries.

Gradually, after many years into his career, Chema became very concerned about the ethical and social issues surrounding the practice of medical and human genetics, and he became a champion for justice and human rights as ethical foundations of science and technology. His interest in bioethics stemmed from his deeply rooted convictions that worldwide controversies regarding issues of life, health and death could and should be resolved through dialogue. At the same time, he was aware that bioethics, like any human endeavor, is very much influenced by social, political and religious forces. Chema subscribed to a progressive and secular view of bioethics, with a clear understanding that the priority for bioethics in an unjust world is to strive for justice and equality. While he was eclectic regarding the ethics of subjects such as embryo selection and abortion, he was appalled at the terrible living conditions of the majority of the world population, particularly in developing countries. He argued that the development of medical technologies based on profit rather than on population health needs, and without social control and state regulation, would only lead to what he called paupericide, which literally means "killing of the poor", resulting from exploitation, discrimination and selective access to new medicines (Cantú, 2005). While he was enthusiastic about developments in genomic medicine, he was cautious about its negative consequences in the absence of universal access to health care guaranteed by the state. In fact, in his writings and lectures, Chema contended that, due to the lack of access of the poor to the advances of medicine, paupericide was already occurring worldwide, a statement that he would back with impressive figures of the differentials of health and mortality between the haves and the have-nots of the world (Cantú, 2005). His commitment to the fight against the economic and political forces causing paupericide led him to espouse the secular and progressive bioethical views of UNESCO, particularly as expressed in the Universal Declaration of the Human Genome and Human Rights and the International Declaration of Bioethics and Human Rights. In 2003, with a group of Latin American bioethicists and support from UNESCO, Chema founded the Latin American and Caribbean Network of Bioethics (Red Latinoamericana y del Caribe de Bioética UNESCO), became its first president and led it to become a dominant bioethics force in Latin America, espousing a secular and progressive brand of bioethics, concerned with social justice and the needs of local populations, and confronting both the Anglo-Saxon and the religious-based brands of bioethics, which, he contended, favor either the political and economic interests of the status quo or dogmatic views of human nature.

Having been dear friends and colleagues for decades, Chema and one of us (VBP) would meet at countless meetings, conferences and congresses all over the world. Of the many memories VBP has of his charisma in expressing his deep convictions and the power of his message to the audiences, of note is Chema's appearance at the International Congress of Bioethics in Brasilia, Brazil, in 2003, where he delivered a lecture on ethics and human rights, which ended with a plea for justice and peace that elicited a long standing ovation.

For one of us (ARM), having been a disciple of Chema, considers it a very distinguished honor, filled with deep learning and fun. Indeed, in addition to clinical and scientific training, Chema would share his experiences and ideals, to the point where many of us participated in his public campaigns in the 1980s against the proliferation of nuclear weapons or in his campaigns in support of Mexican indigenous communities. Chema not only guided his students in graduate school programs but, thanks to his multiple national and international contacts, helped us to continue our postdoctoral training in centers of excellence, becoming a permanent mentor. He accomplished this task by phone and written communications or through surprise visits he made to those who were abroad any time he was 
able to reach someone during his travels. Many of his disciples continue the research and academic cooperation he encouraged, and I am sure we are all marked with the indelible stamp of his memory.

This tribute to Chema Cantú would be absolutely incomplete without mentioning that he was a man of profound and exquisite culture, with extensive personal interests beyond science, such as music, art and philosophy and that he was an accomplished painter and art collector. He was also a loving father of Cristina, Susana and Nancy, the three daughters he had with his first wife, of his son José María ("Chemita") and of his youngest daughter, Lakshmi, born to Mariela, the love of his life and his devoted wife since 1989, who cared for him with endless love in Buenos Aires during his protracted suffering from stomach cancer, of which he eventually died on November 12, 2007.

Chema Cantú's scientific excellence, humanity, quest for social justice and equality as well as his love for life and humankind has left an indelible legacy in the science of human genetics and bioethics in Latin America.

\section{References}

Cantú JM (2005) El respeto a la vida: diagnóstico prenatal, aborto eugenésico y clonación terapéutica. Diálogo Político. Konrad Adenauer Stiftung, 22(2):19-38.

Cantú JM and Ruiz C (1985) On atavisms and atavistic genes. Ann Genet 28:141-142.

Cantú JM, García-Cruz D, Sanchez-Corona J, Hernandez A and Nazara Z (1982) A distinct osteochondrodysplasia with hypertrichosis - Individualization of a probable autosomal recessive entity. Hum Genet 60:36-41.

de Andrés F, Sosa-Macías M, Lazalde-Ramos BP, Naranjo ME, Tarazona-Santos E and

Llerena A (2013) Evaluation of drug-metabolizing enzyme hydroxylation phenotypes in Hispanic populations: the CEIBA cocktail. Drug Metabol Drug Interact 28(:135-146.

García-Cruz D, Sánchez-Corona J, Nazara Z, García-Cruz MO, Figuera LE, Castañeda V and Cantú JM (1997) Congenital hypertrichosis, osteochondrodysplasia, and cardiomegaly: further delineation of a new genetic syndrome. Am J Med Genet 69:138-151.

García-Ortiz JE (2008) In Memoriam. José María Cantú (19382007). Am J Med Genet 146A:1773-1774.

Hall BK (1984). Development mechanisms underlying the formation of atavisms. Biol Rev Camb Philos Soc 59:89-124.

Harakalova M, van Harssel JJ, Terhal PA, van Lieshout S, Duran K, Renkens I, Amor DJ, Wilson LC, Kirk EP, Turner CL, et al. (2012) Dominant missense mutations in ABCC9 cause Cantú syndrome. Nat Genet 44:793-796.

Llerena A, Dorado P, Ramírez R, Calzadilla LR, Peñas-Lledó E, Alvarez M,

Naranjo ME, González I, Pérez B, CEIBA Consortium of the Ibero-American Network of Pharmacogenetics \& Pharmacogenomics RIBEF (2013) CYP2D6 -1584C > G promoter polymorphism and debrisoquine ultrarapid hydroxylation in healthy volunteers. Pharmacogenomics 14:1973-1977.

Macías-Flores MA, García-Cruz D, Rivera H, Escobar-Luján M, Melendrez-Vega A, Rivas-Campos D, Rodriguez-Collazo F, Moreno-Arellano I and Cantú JM 1984) A new form of hypertrichosis inherited as an X-linked dominant trait. Hum Genet 66:66-70.

Rangel-Villalobos H, Rivas F, Sandoval L, Ibarra B, GarcíaCarvajal ZY, Cantú JM and Figuera LE (2000). Genetic variation among four Mexican populations (Huichol, Purepecha, Tarahumara, and Mestizo) revealed by two VNTRs and four STRs. Hum Biol 72:983-995

van Bon BW, Gilissen C, Grange DK, Hennekam RC, Kayserili H, Engels H, Reutter H, Ostergaard JR, Morava E, Tsiakas $\mathrm{K}$, et al. (2012) Cantú syndrome is caused by mutations in ABCC9. Am J Hum Genet 90:1094-1101.

Zhu H, Shang D, Sun M, Choi S, Liu Q, Hao J, Figuera LE, Zhang F, Choy KW, Ao Y, et al. (2011). X-linked congenital hypertrichosis syndrome is associated with interchromosomal insertions mediated by a human-specific palindrome near SOX3. Am J Hum Genet 88:819-826.

License information: This is an open-access article distributed under the terms of the Creative Commons Attribution License, which permits unrestricted use, distribution, and reproduction in any medium, provided the original work is properly cited. 